\title{
Evaluation of Academic Experience in Learning Education over Simulator Softwares
}

\author{
Carlos Alexandre Gouvea da Silva* \\ *Departamento de Engenharia Elétrica, Universidade Federal do Paraná, Curitiba, Brazil. \\ E-mail: carlos.gouvea@ufpr.br \\ Edson Leonardo dos Santos \\ •Departamento de Engenharia Elétrica, Universidade Federal do Paraná, Curitiba, Brazil. \\ E-mail: edson_l@hotmail.com \\ Douglas Antonio Firmino Pelacini \\ `Department of Electrical Engineering, Universidade Federal do Paraná, Curitiba, Brazil. \\ E-mail: douglaspelacini@hotmail.com
}

\begin{abstract}
This article presents an overview of simulated Education through computational tools. In recent years, educational institutions have been working even harder in the application of virtual teaching and learning environments, which are available to different undergraduate and technical courses. During the learning process, the student is invited to try out some forms of different subjects and learning contents. The use of technologies gained a lot of space in these institutions in order to allow students to experiment different theories in practical settings. Simulators allow students to conduct hands-on experiments without need for real environments, which consequently generates costs and also a effort of planning. This presents a study on software simulators applied in different technological courses. After the application of the simulators, students were invited to answer a Quiz in order to understand the effectiveness of the simulators use in the learning of each one. Results show that students considered the use of simulators as advantageous and important, but it is still not enough to suppress the use of practical classes in real environments.
\end{abstract}


24 ISSN: 2358-1271. Int. J. of Alive Eng. Educ. (IJAEEdu). (Online). Goiânia, v. 2, n. 5, p. 24-40, July/Dez. 2018.

Keywords: Engineering Education, Environments Teaching, Simulation learning, Theoretical and Practice Learning.

\section{Introduction}

In recent years, Education models have been presented to students with various changes. This condition allowed improvements in the way that teaching methodologies enter the daily life of students, especially on the modalities of Face-to-Face or Distance Education. Therefore, technologies present challenges in Universities and Institutes of Education, especially in distance courses. If on the one hand, in each institution, students are trained and educated on specific themes and areas of knowledge; on the other, pedagogical models of learning and Education try to shape students in traditional and obsolete methodologies that, in same cases do not allow students thinking freely and develop their interpersonal skills ${ }^{1}$.

In Brazil, the growing need for higher-quality professionals and the political laws of social access to poor people allowed new graduate courses in Engineering to be created $^{2}$. Estimates of access at undergraduate levels have shown that in Latin America the number of students entering Universities up to $21.0 \%$ between the years 2000 and 2013, and in Caribe this average is higher than $43.0 \%^{3}$. This scenario generates a demand for learning models in different modalities, specially in Face-to-Face Education.

After high school, the student can choose the modality of his own undergraduate, and if he chooses the Face-to-Face Education, all the information is transmitted by a professor or tutor during the academic life ${ }^{3}$. Otherwise, in Distance Education the student has access to information in virtual environments that are developed by the institution itself with free access to books, papers, discussion forums, classes, simulation softwares, virtual learning activities and environments.

Virtual Learning Environments (VLE) are social and learning spaces for educational iterations where students are not only active, but also the actor who helps to improve and build the space. These VLE are not restricted to Distance Education, but can be used by students in classroom activities ${ }^{4}$. In parallel to VLE, the simulators present an opportunity where the student can improve the technical qualities and extend the skills in special areas such as Engineering and Technological courses. Universities with low financial resources may present serious problems to teach subjects where practical activities and experiments with equipment, machines, components and test environments are crucial, then opening a new opportunity for the use of simulators.

In this paper, it is proposed the application of simulation softwares in the activities of the students, in order to analyze the student's perception before and after its use. The purpose is to show if this methodology improves the learning in Engineering and technological courses. ${ }^{5}$ With this introduction section, the Section 2 presents an overview about the learning Education process and how the student can extract useful information in theoretical classes. In Section 3 some simulators are presented in order to learning experiments. The methodology and procedures used in this study are shown in Section 4. The Section 5 shows the results and, finally, Section 6 presents the conclusions.

\section{Learning Education Process}

Education in the world has changed in several aspects. This allows the new challenges to become reality in Institutes of Education such as Schools and Universities. In addition, the learning process must be able to undergo transformations in order to allow students to build a collaborative study environment and maximize learning information. 
In Schools and Universities, the classic educational system has based on two main elements: the professor and the student. The professor transmits his knowledge to the student whereas the student listens to the information to assimilate all knowledge and to make notes, written or direct questions. Outside of class, the student should schedule their learning process in group studies or lonely ${ }^{6}$. Learning is the acquisition of new mental schemes, knowledge, skills, abilities, etc., that can be used to solve elementary, difficult and complex problems in different areas, making use of tools, simulators, mathematical equations, theories and analytical analyzes. These solutions are possible after the effective understanding of knowledge and its correct application ${ }^{7}$.

In this context, "learning" can be explained in different ways. Felder and Silverman (1988) describe learning as a two-step process structure involving a receiving step and a processing step. In information processing, an external source has become available to students, who select and rb crucial information and drop the rest ${ }^{8}$. Armstrong and Fukami (2009) define learning as a holistic process of adaptation, which not only results in positive conclusions about cognitive learning, but involves the total integrated functions of people, such as thinking, feeling, perceiving and behaving for problem-solving, decision-making and creativity using ${ }^{9}$. For Prince and Felder (2006) the evolution of Education has created new paradigms such as inductive teaching and learning, which is a set of a variety of instructional methods, including question-based learning, problem-based learning, project-based learning, case-based teaching, discovery learning, and just-in-time teaching ${ }^{10}$. Understanding student learning modes, style, and preferences helps to choose explanatory or demonstrative approaches and materials tailored to their learning style preferences ${ }^{11}$.

Students as a Center of Educational learning must have the skills to enable easy and effective learning. During a learning process, students are challenged against a set of different learning styles. Figure 1 presents the Learning Style Schema models. Learning based on this model shows a general concept when "perception", "input", "organization", "processing" and "understanding" are the dimension to allow students assimilate all learned information". In the same model, adding "tool" as base of educational environments allow creation of individual or collective scenarios, where students can share knowledge in groups. In "input" the most effectively perceived information about visual effects such as images, diagrams, graphs, and demonstrations that may include the use of Education or non-Education simulation software.

Students should be aware of their development and evaluate their own progress through a portfolio, personal development record or other form of personal development planning. The use of practical works in laboratory play a great alternative in the leaning Education of experimental activities. In this environment the student learns to develop skills and attitudes using simulators softwares. Experimental real activities are very expensive in terms of staff time, support staff, consumable materials and equipment. Thus, simulators have become in recent years an alternative to the learning of Education and are vital for the development of practical, discipline-specific skills, in addition to providing rich opportunities for the development of intellectual skills ${ }^{12}$. For Fry, Ketteridge and Marshall (2008) there are a set of advantages in practical works such as: gain practical skills; gain experience of particular techniques or pieces of equipment; make links between theory and practice; make observations; formulate and test hypotheses; develop problem-solving skills; develop personal skills; develop safe working practices; motivate and enthuse students; and simulate professional practice ${ }^{12}$. That advantages working together with pedagogical process became the learning more effect, because can be used as a basic structure in order to help and give support to students during class. 


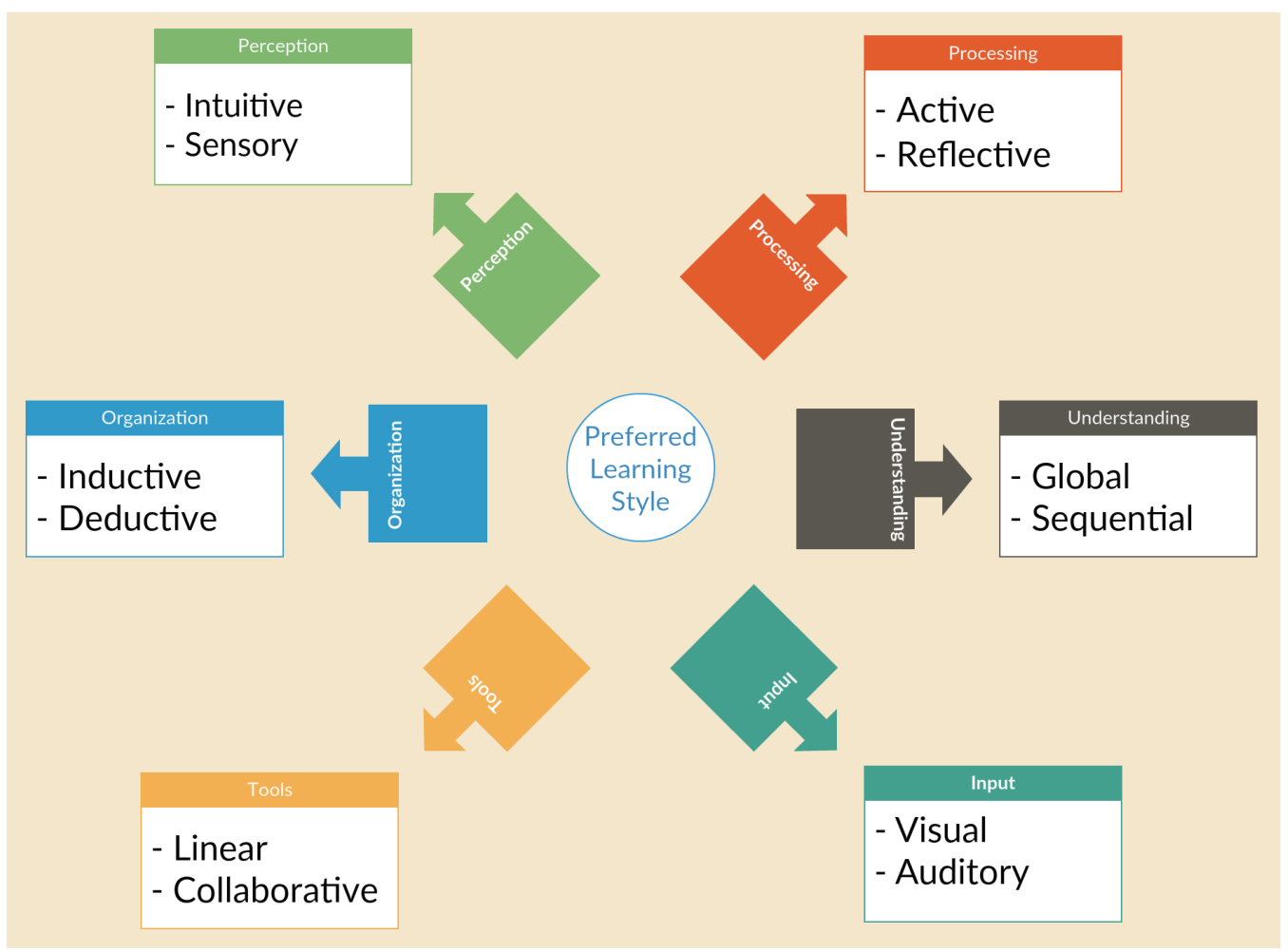

Figure 1. Dimensions of Learning Styles ${ }^{8}$.

\section{Educational Computer Simulators}

Educational software is a computer program used by students and professors to improve the learning process between both. For students, educational softwares can precipitate the willingness to learn due to its typical interactive nature and visual content. For professors, these softwares are a set of tools that will help students to understand more deeply the concepts of the specific subject that they teach.

Educational software generally makes use of visual and auditory effects. This because students are usually more willing to listen and cheer up when the presentation in front of them is visual-oriented. This also helps to let them understand a specific subject in more depth. The visual content of the educational software program usually consists of graphics, animations and videos. Educational programs can also have interactive games that can help students understand the program. These are meant to be interesting, even if it is academic in nature, so that students do not feel bored or pressured to participate.

Simulators have gained importance in learning Education due to high level of iteration between students and interpretation of theory. A simulator is a device, equipment or software that allows to reproduce and simulate a specific environment from the real behavioral system. Software simulator attempts to represent a condition that presents similar results from the use of the same input informations. In many cases, students do not have facilities during the association of professor information in real situations of real scenarios. In classes, the most difficult requirement is for the professor to decide which educational software is being used with the student, which allows rapid, positive and useful assessments of the simulator usage behavior, for example ${ }^{13}$. Constantly simulators have been used in different educational 
institutions and are not exclusive for technological areas as Engineering and Computing. Simulators are used, for example, in the area of health education ${ }^{14,15,16,17}$.

In Engineering and Computing Education the simulators became essential for learning process of Engineers due to the ease in reproducing many experiments and situations without the need of real equipment, visitation in technical spaces, safety equipment and resources for theoretical understanding and practical works. Electrical Engineering undergraduate Education can be cited the following simulators: Proteus software allows to simulate Digital Electrical and Electronic Projects; simulator SO-sim is a framework for learning about Operating Systems; Crocodille and ATPDraw are used for electrical circuits; and MATLAB software for different simulations. Araujo et. al. (2016) presents a rich paper for using interactive simulator in Electronic Engineering ${ }^{18}$. In Weingartner, Lehn and Wehrle (2009) the authors present an overview of computer network simulators, not for learning education, but they open the opportunity for the future using ${ }^{19}$.

Nikolic (2009) presents an overview about the simulators suitable for teaching courses in computer architecture and organization. The author further states that the main challenge of working with this subjective is to prepare the student for real situation in order to understand a computer architecture ${ }^{20}$. To enable students in computer networks, Janitor, Jakab and Kniewald (2010) present the main contributions and statistical from using the Cisco Packet Tracer in classrooms ${ }^{21}$. The Cisco Packet Tracer is one of the most traditional student simulator for computer networks and is used in this paper. Balamuralithara and Woods (2009) described a Virtual Laboratories in Engineering Education to Electronic Digital activities. Results show that virtual environments improve and stimulate the students to study intensity in free time ${ }^{22}$. The Proteus simulator is used for teaching microcontroller to students of Engineering courses. Proteus is especially suited to teach students about the Design and Operation of Systems based on microcontrollers ${ }^{23}$.

A comparative of laboratory work on simulators and hands-on laboratory in Electronic courses is presented by Taher and Khan $(2015)^{24}$. During 8 weeks, 24 students were encouraged to use circuit simulators and compare with real experiments. The main purpose of the study was answer the following questions: 1) Does using simulation improve student learning outcomes? 2) How do faculty members perceive the use and effectiveness of simulation in delivering technical course content? 3) How do students perceive the instructional design features embedded in the simulation program, such as exploration and scaffolding support in learning new concepts? In all cases, students respond positively to the simulator using one questionnaire applied in the final study. Ma and Nickerson (2006) presented a comparative literature review about hands-on, simulated and remote laboratories, which are describe several learning aspects about laboratories activities for different courses ${ }^{25}$.

\section{Methodology}

To analyze the positive impact of simulator on educational learning, this study is divided in three steps: first the classes choosing where the study will be applied; second the methodology of application simulators over exercises or challenges to students; and finally analyze the learning aspect in the student's feeling from the application of a Quiz. Steps are presented as follows.

\subsection{Choosing Classes}

Initially, different classes were chosen to apply the methodology of this study. Two levels of Education in the technological area were chosen: technical course level (similar to 
high school) and undergraduate level (bachelor degree). Table 1 shows the relation of classes and number of students. Electronic simulators were applied to students of technical level of a Public Federal Institution and computer network simulators were applied to system computer students of a Private Center University. The students of Electrical Engineering are from a Federal University of different progress of course and were invited to participate in the Quiz after using Electronic and Network simulators.

Table 1. Relation of students and courses.

\begin{tabular}{|c|c|c|}
\hline Level & Course & Amount \\
\hline \hline Technical & Electronic & 30 students \\
\hline Undergraduate (bachelor) & Electrical Engineering & 72 students \\
\hline Undergraduate (bachelor) & Information of System & 25 students \\
\hline Undergraduate (technological) & Development and Analysis of Systems & 18 students \\
\hline
\end{tabular}

\subsection{Applying Simulators}

In this design was used of simulators in three different disciplines of the courses: (1) Logic Circuits in Electrical Engineering course; (2) Computer Networks in Information of System course, in Development and Analysis of Systems course and also in Electrical Engineering course; and (3) Digital Circuits in Technical Electronic course. The period of study was from january 2018 to july 2018, and is presented in Figure 2.

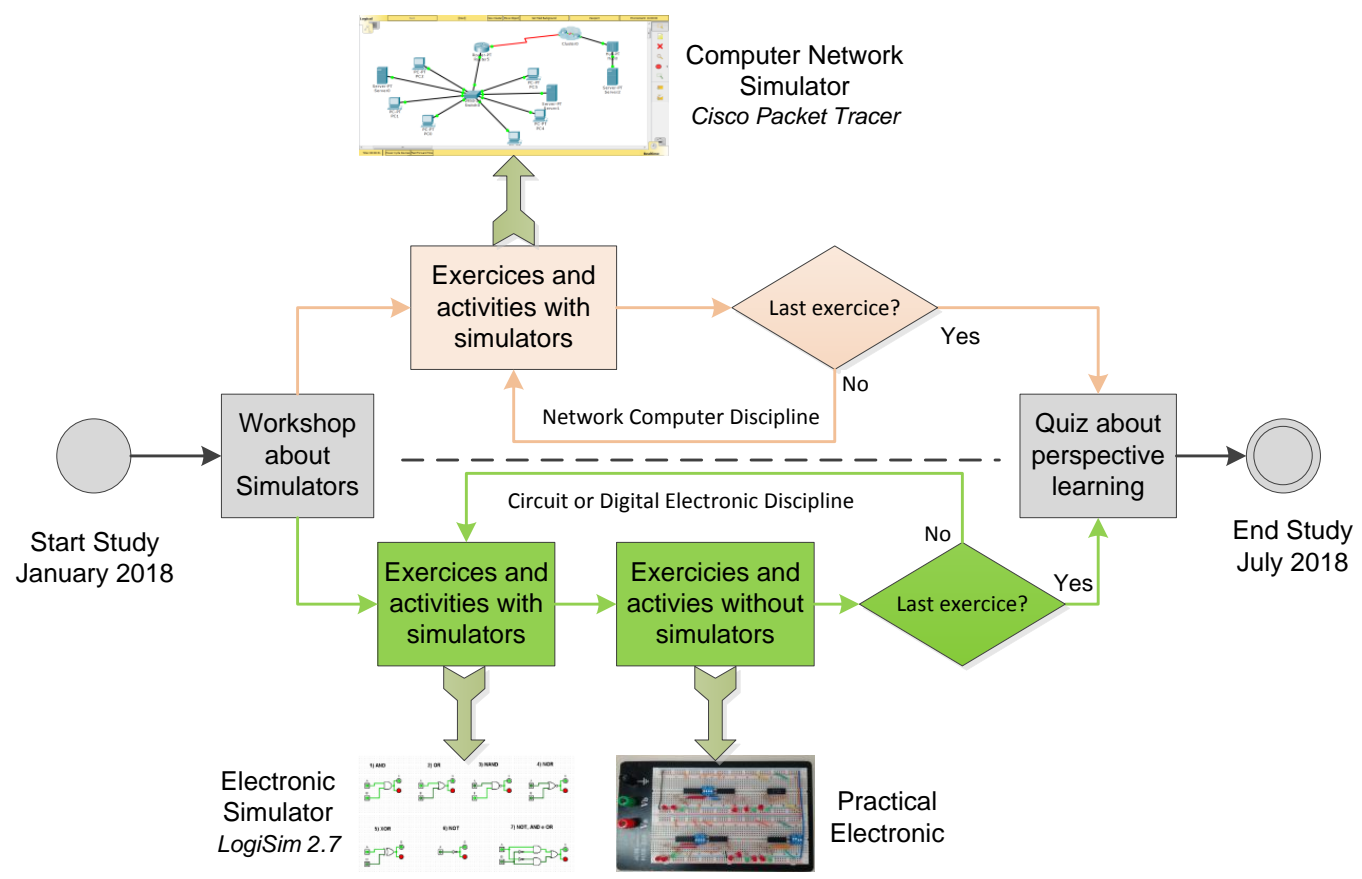

Figure 2. Methodology sequence.

In the first activities the students participated in workshops when several simulators were demonstrated. The Computer Networks class had an overview about the Cisco Packet 
Tracer. That educational simulator was created by Cisco to prepare students for certifications of Cisco equipments ${ }^{26}$, but can be easily used for teaching networks in different courses. In Digital and Logic Circuits disciplines was worked with Falstad, Everycircuit, Logic Simulator, Logisim, EasySim, Part SIm, Proteus and Multisim.

In the second step, the classes had to accomplish simple activities with a tutor orientation using simulators. In Digital and Logic class, the student could free choose the simulator from an available list and the students carried out 10 activities. In the Computer Networks class, students performed three activities. After the simulation, each class had to perform the same activities with real components, equipments and machines, except for Computer Networks class. The second case, the real experiment was not performed, since the institutions do not have equipment such as: routers, switches, access points, Unshielded Twisted Pair (UTP) network cables, connectors RJ45, modems and Ethernet or Wireless devices. The main objective was to compare the results of simulation with the practical experiment.

\subsection{Quiz evaluation}

In the last step of the proposed methodology, a Quiz was applied to the students. The "affirmatives" are presented as follows, where the student had to match in five levels alternatives ( 1 - totally disagree, 2 - partially disagree, 3 - not agree and not disagree, 4 partially agree, and 5 - totally agree).

The affirmatives are presented in Frame 1.

Frame 1. Quiz about the use of simulators.

\begin{tabular}{|c|c|}
\hline Number & fffirmative \\
\hline 1 & The use of simulators aroused the interest of student in the studied content. \\
\hline 2 & The use of simulators facilitates the learning of new contents and concepts. \\
\hline 3 & $\begin{array}{l}\text { The use of simulators facilitates the accomplishment of the practical activities } \\
\text { and of studying the contents. }\end{array}$ \\
\hline 4 & $\begin{array}{l}\text { The use of the simulator allows the expansion of knowledge beyond theoretical } \\
\text { content. }\end{array}$ \\
\hline 5 & The use of simulator has extended its technical knowledge in the field. \\
\hline 6 & $\begin{array}{l}\text { tor allowed the conceptual and procedural understanding } \\
\text { vity. }\end{array}$ \\
\hline 7 & The use of the simulator allowed the argumentation from the simulated results. \\
\hline 8 & $\begin{array}{l}\text { The use of the simulator allowed to identify the difficulties that can arise in a } \\
\text { circuit and network implementation. }\end{array}$ \\
\hline 9 & $\begin{array}{l}\text { Experimental practice has extended its technical knowledge in the field of logic } \\
\text { circuits and networks. }\end{array}$ \\
\hline 10 & $\begin{array}{l}\text { The use of the simulator is dispensable for performing the experimental prac- } \\
\text { tice. }\end{array}$ \\
\hline 11 & \\
\hline 12 & $\begin{array}{l}\text { m the simulators currently available, it is possible to state that the practice } \\
\text { digital circuits and computer networks may be entirely non-presence. }\end{array}$ \\
\hline
\end{tabular}

A thirteenth question about "What characteristics made you choose the simulator used in the simulator experiment?" was applied to students. After applying the Quiz, the results are quantified and presented in section 5 .

In order to measure the positive or negative effects of the simulators in the classes, we analyze the performance of a historical final status of a few classes. Two specific classes 
of Electrical Engineering were considered: (a) Logic Circuits: between 2009 to 2018, where simulators with students have been used since 2015. The total performance was 919 students enrolled; and (b) Computer Networks: between 2012 to 2018, where the simulator was applied in only one special class in 2018. The total performance was 344 students enrolled.

It was considered by measure, the following status: Approved (score $\geq 50.0$ ), Reproved by presence frequency (frequency $<75.0 \%$ ), Reproved by low score (score $<50.0 \%$ ) and Give up. In this case, there is a probability that the same student has tried twice or more times the discipline.

\section{Results}

From Graphics 1,2,3,4,5 and 6 the results of the Quiz are shown by affirmatives one to six. It is possible to prove that students approve the use of simulators to create new initiatives and perspectives on technical subjects. For them, simulators improve the knowledge in most of students interviewed in the Quiz. For Computer Network class, the interesting is more effective than in other class, due facility understanding of the simulator and the fact that the simulator is an educational building tool. Another aspect that can be observed in the Cisco Packet Simulator is the student interaction facility to see the entire transmission of messages and packets.

Same students think that practical experiments and activities need to be done in parallel with simulator, where this affirmative is confirmed when verified in affirmative seven, as shown in Graphic 7. In this sense the students are call to evaluation and compare the results between experimental exercises and simulation. From simulated results, students may question possible incorrect answers and thus indicate alternative solving problems.

Graphic 8 depicts that some implementation problems are still not entirely clear to students, because for them the simulation environments do not represent $100.0 \%$ of a real scenario. In Graphic 9, for the majority of students, the use of simulators allows increased learning knowledge in technical subjects.

In affirmative ten, most students think that the simulator may not influence if there are technical laboratories available with complete equipments, components and resources, as shown in Graphic 10. Then, the simulator is a great tool for co-working with classroom practice experiments.

Graphic 11 presents the feeling of excluding experimental exercises if simulators are available. Even with good contributions, students find it crucial for learning improvement that practices should be maintained.

In the last affirmative, students were asked about the existence simulator, which can replace face-to-face classes in Universities or Institution of Education. For the most students, as shown in Graphic 12, even knowing this contribution of simulator in education, it is not yet possible to replace traditional learning when the student has to attend classes in the rooms. For $10.0 \%$ of the students, the computer network classes can be taught in distances disciplines. 


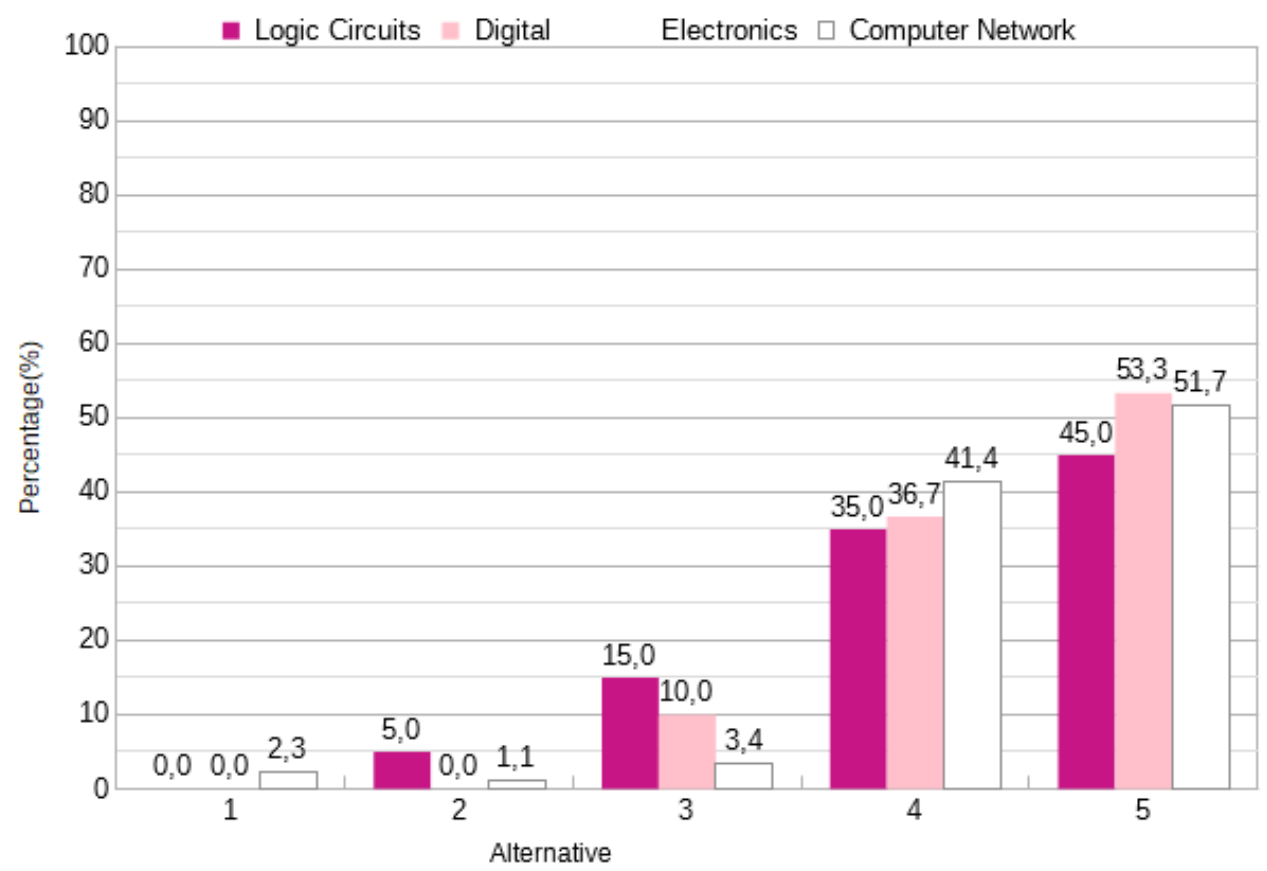

Graphic 1. Affirmative 1 results.

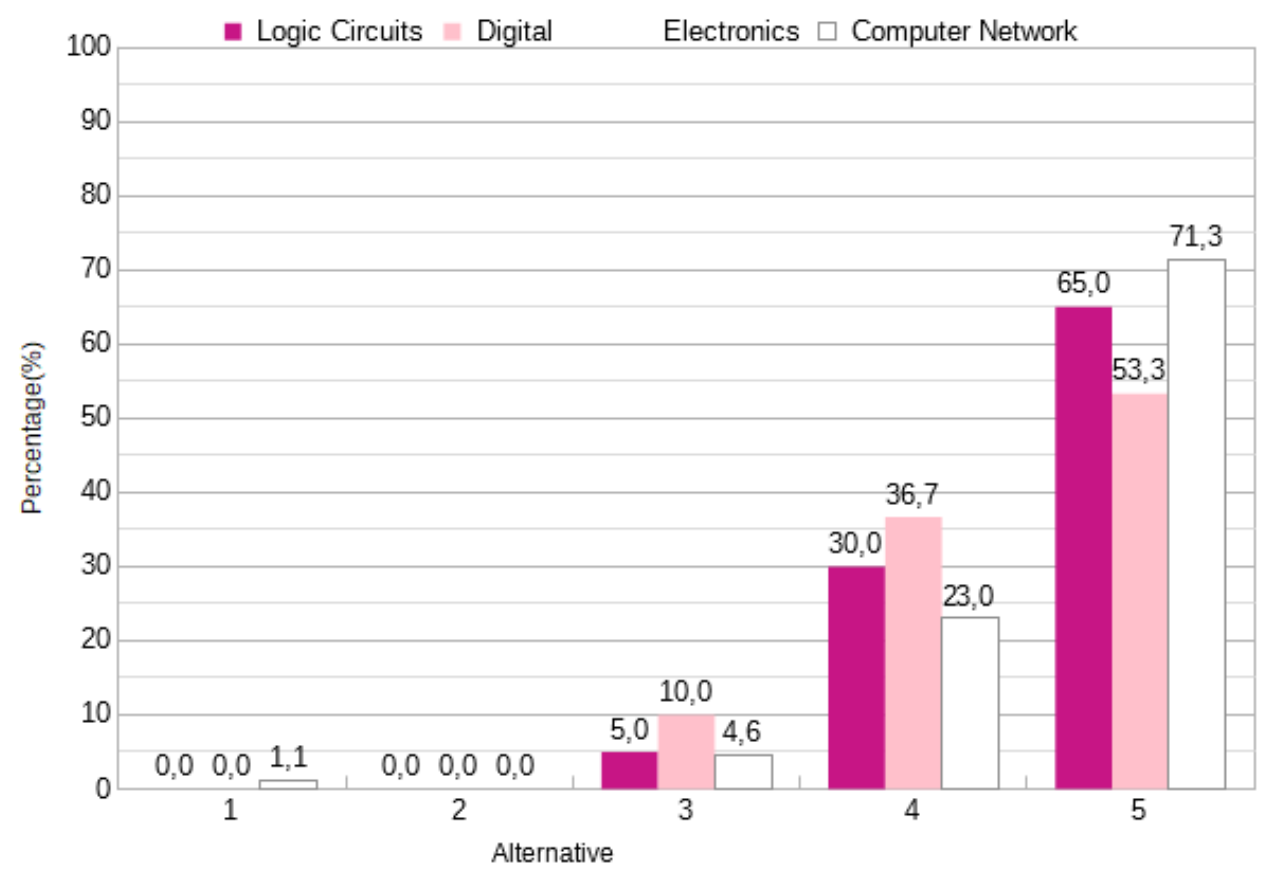

Graphic 2. Affirmative 2 results. 


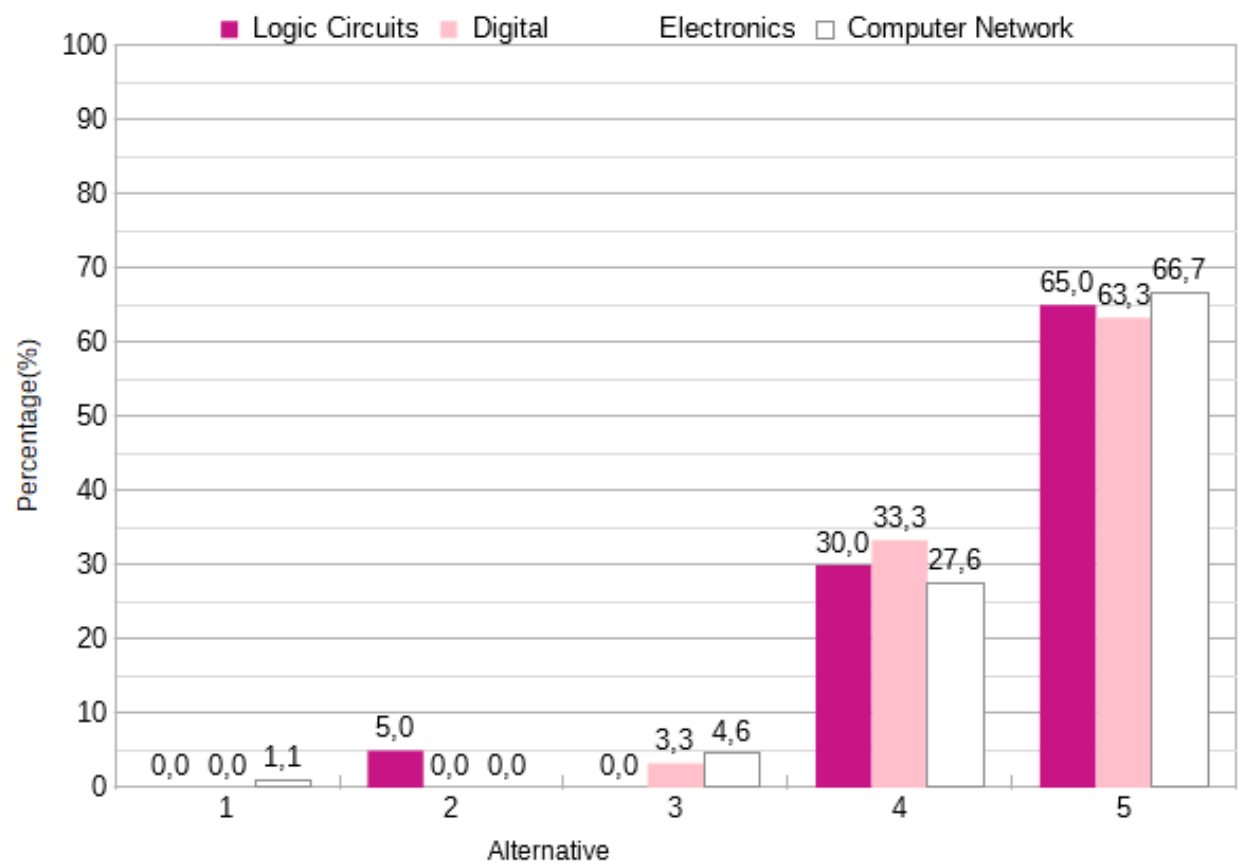

Graphic 3. Affirmative 3 results.

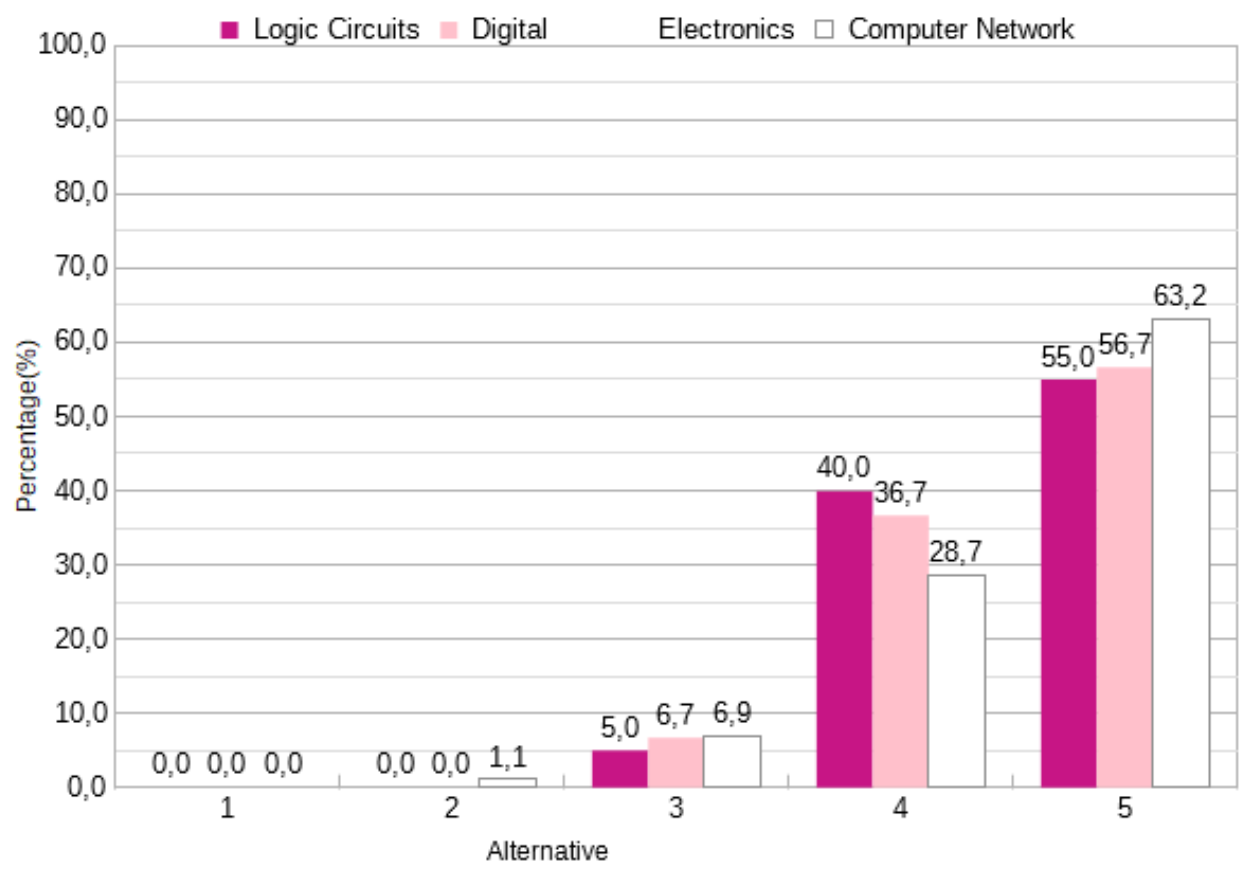

Graphic 4. Affirmative 4 results. 


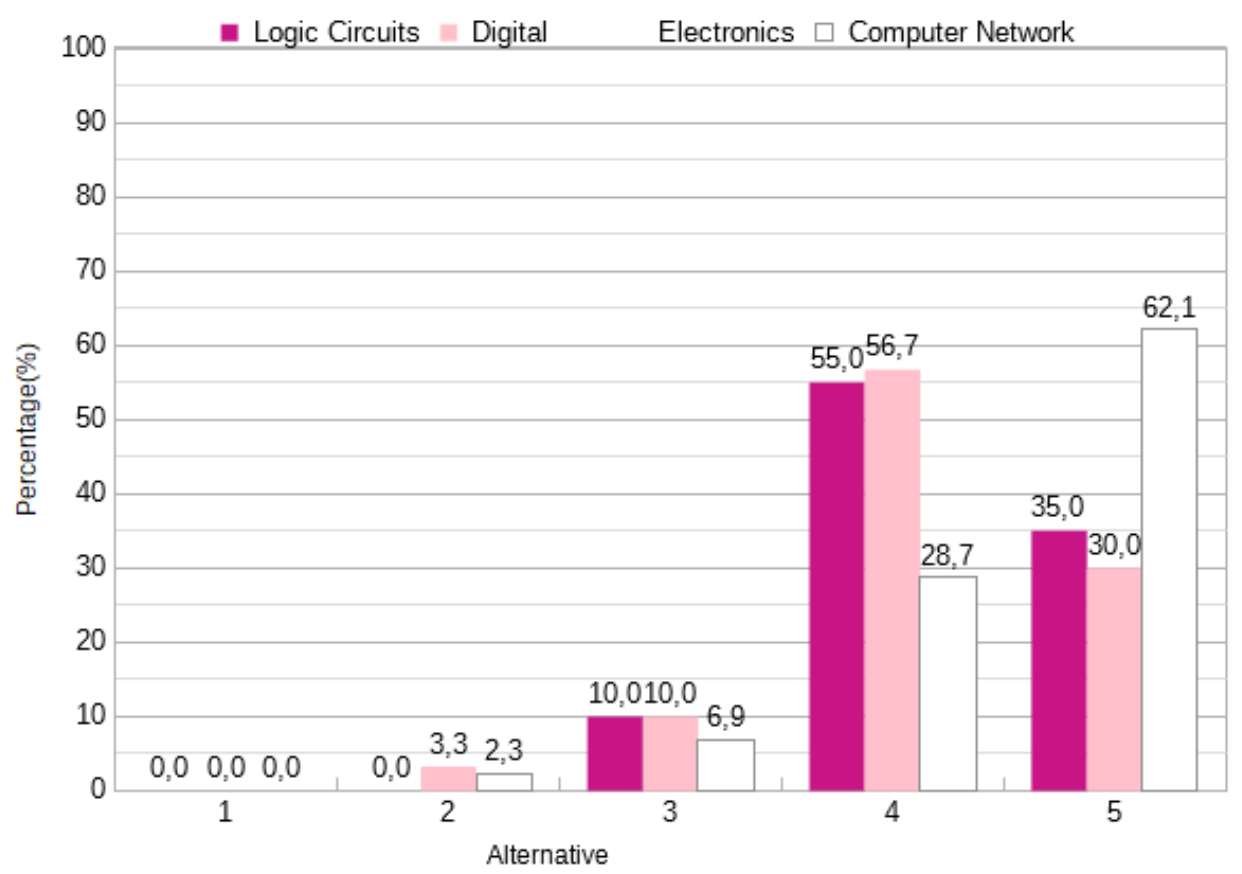

Graphic 5. Affirmative 5 results.

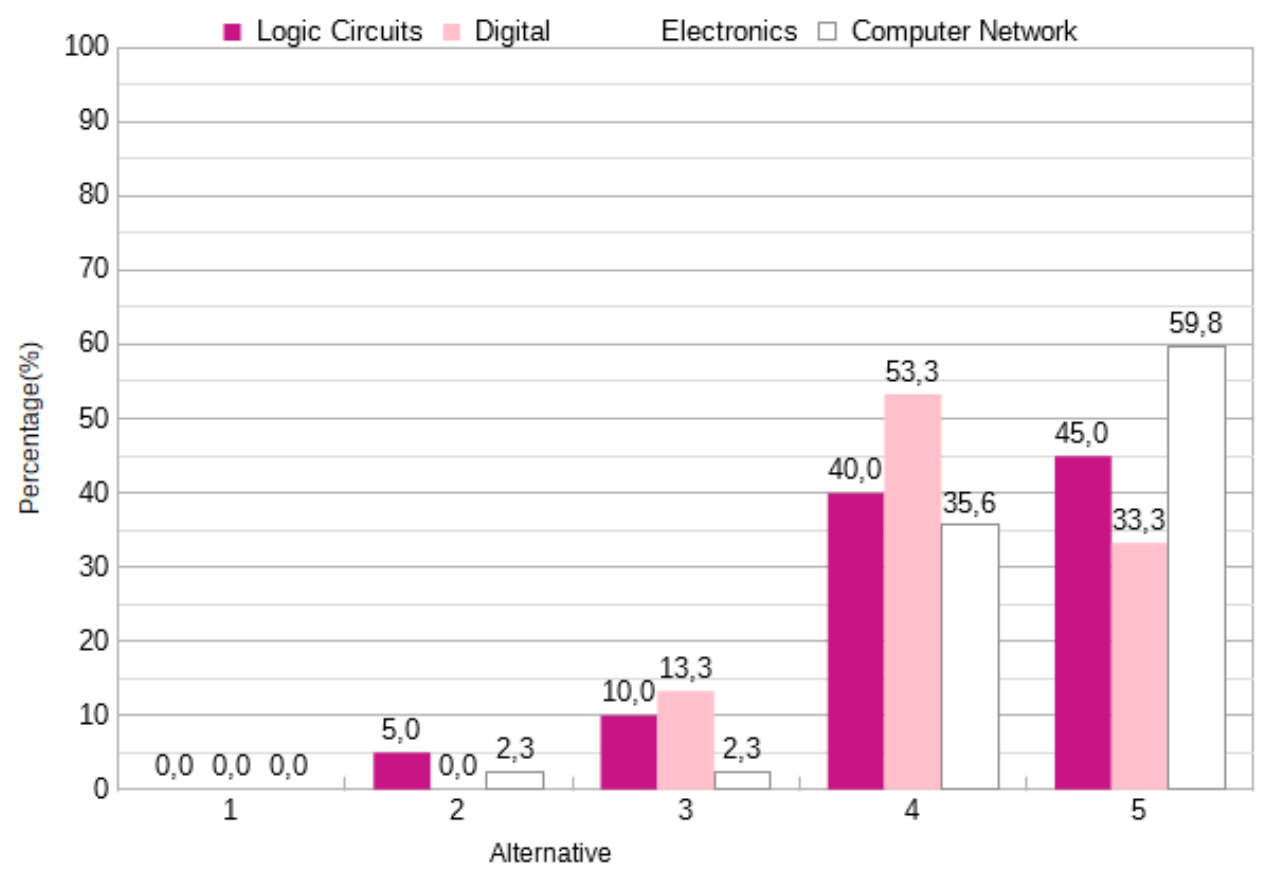

Graphic 6. Affirmative 6 results. 


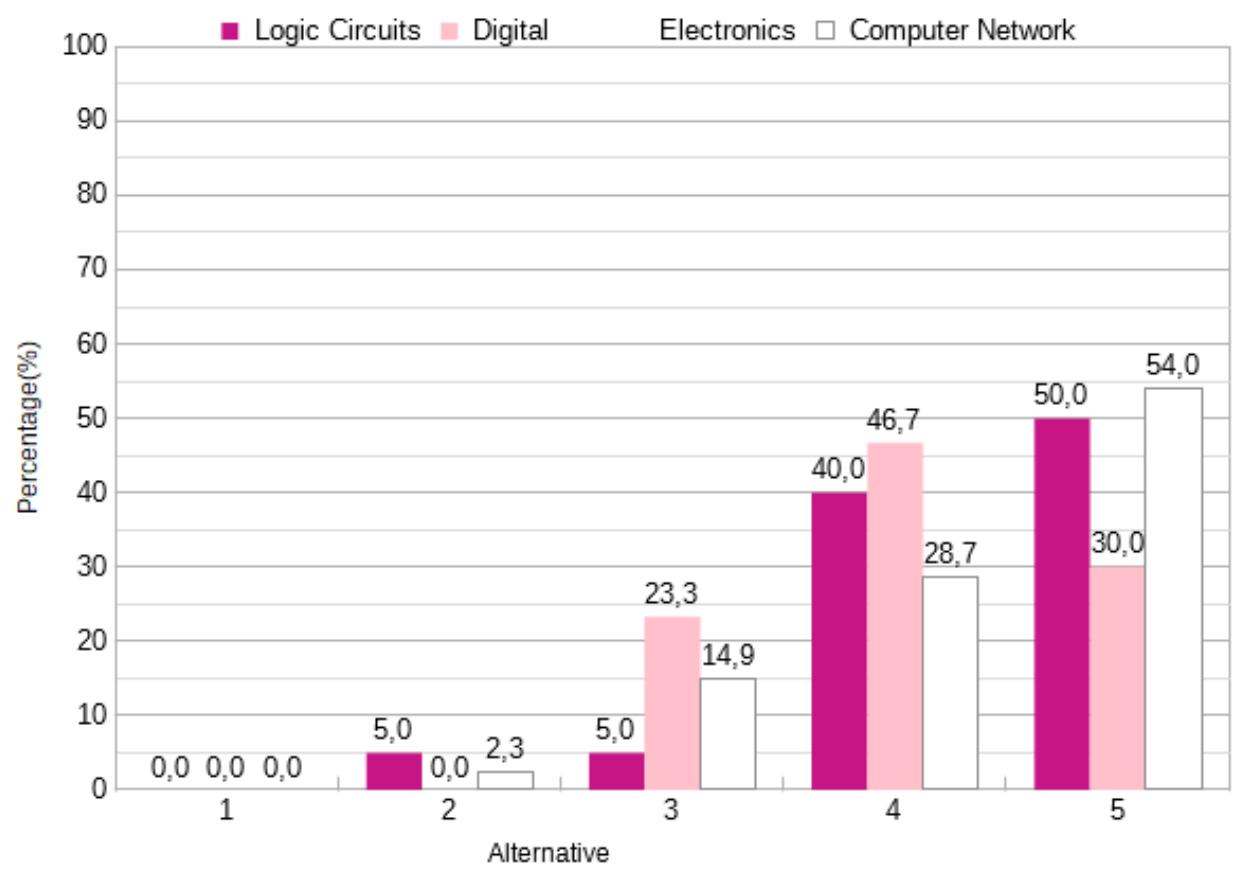

Graphic 7. Affirmative 7 results.

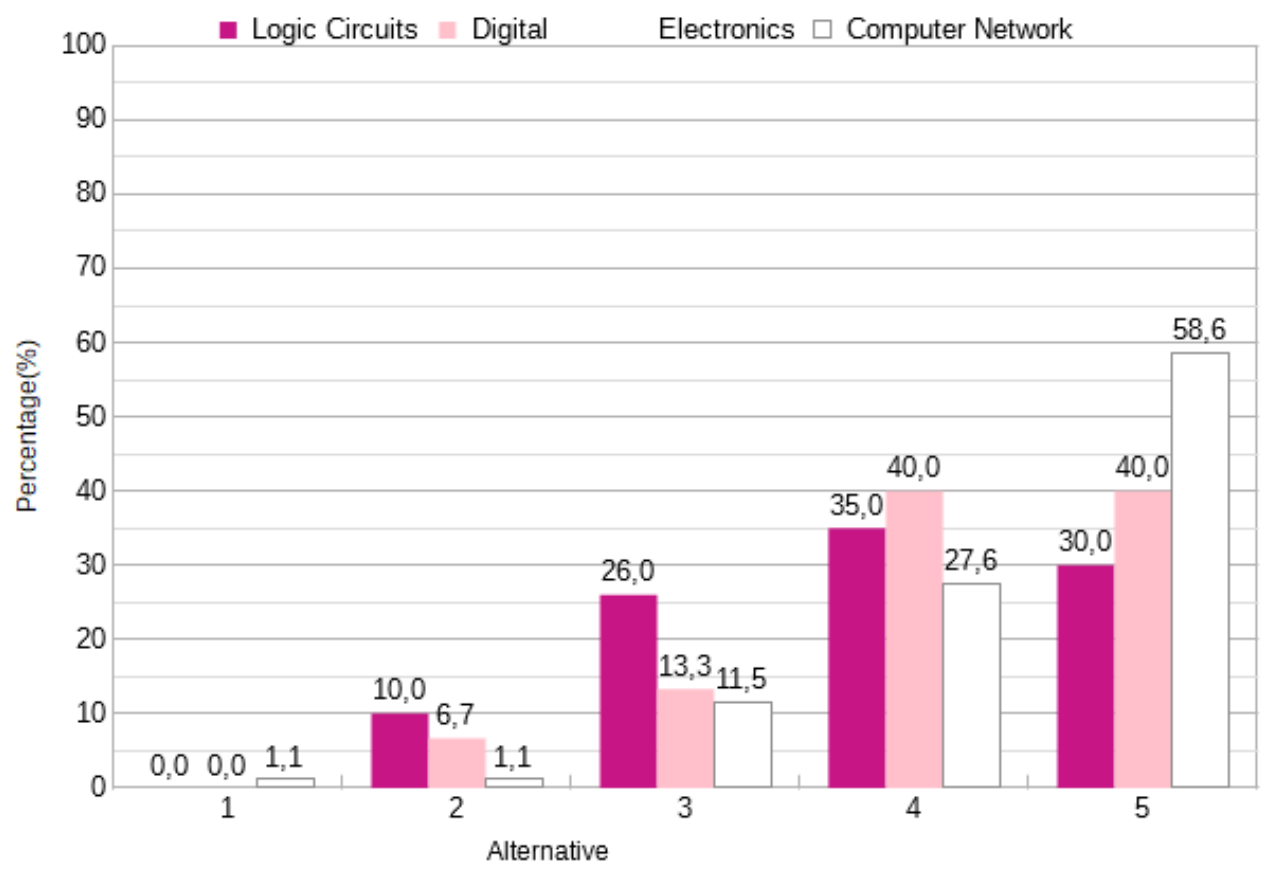

Graphic 8. Affirmative 8 results. 


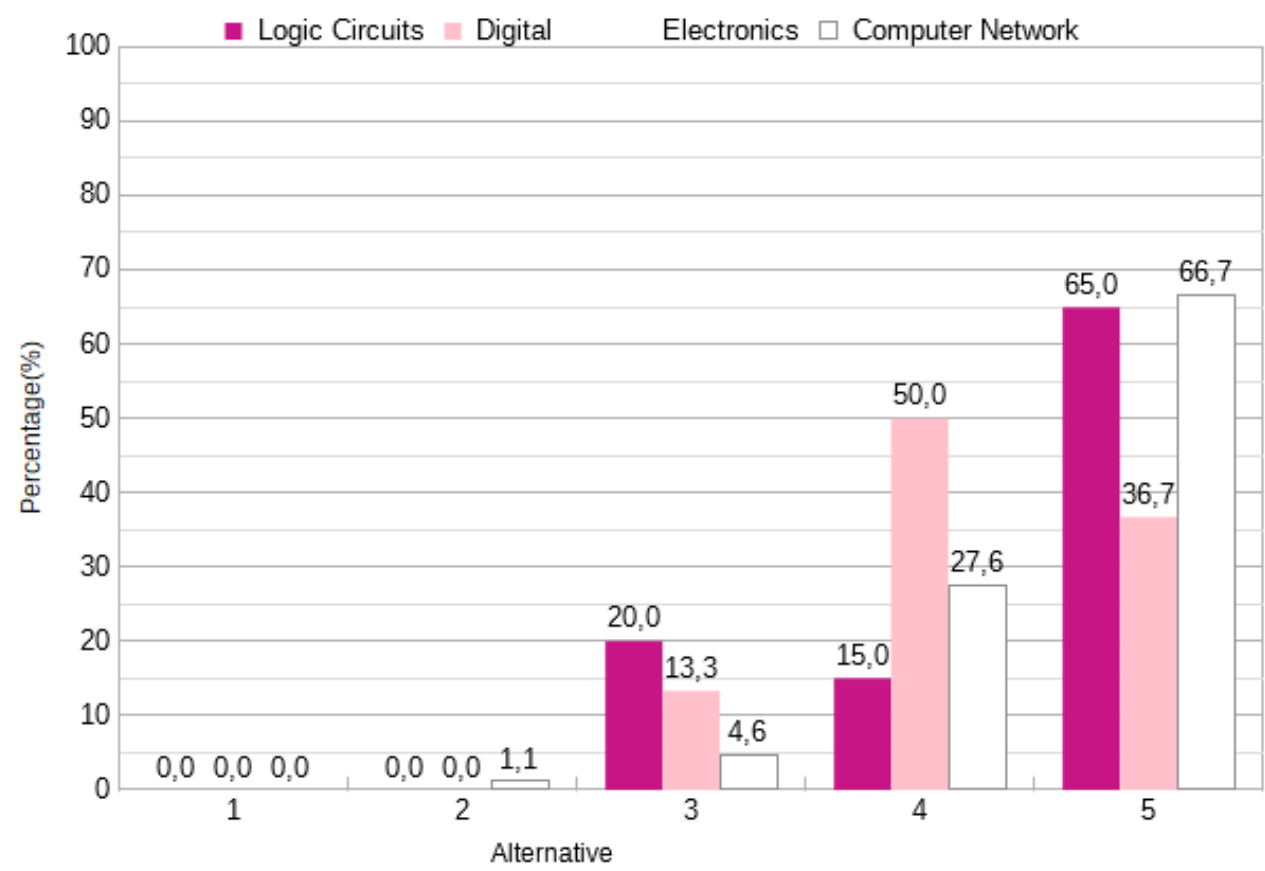

Graphic 9. Affirmative 9 results.

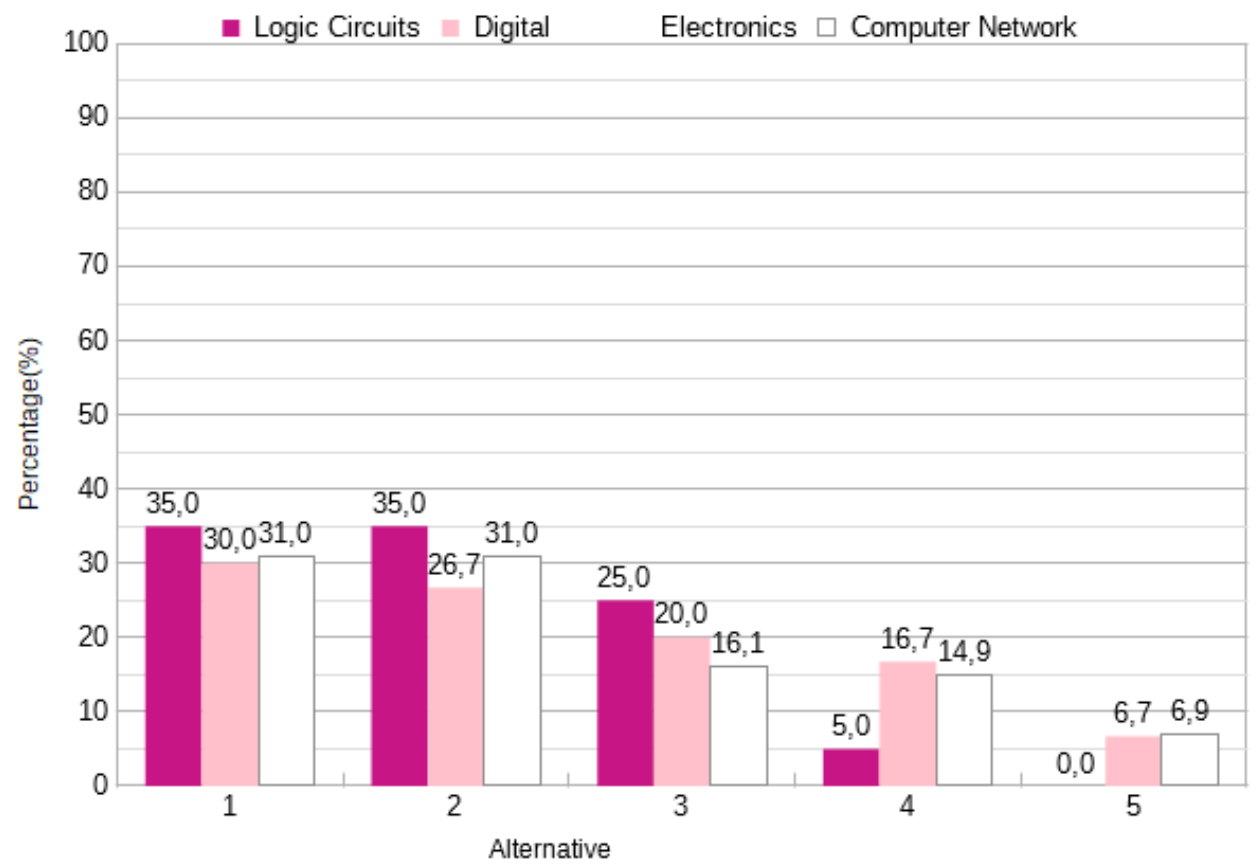

Graphic 10. Affirmative 10 results. 


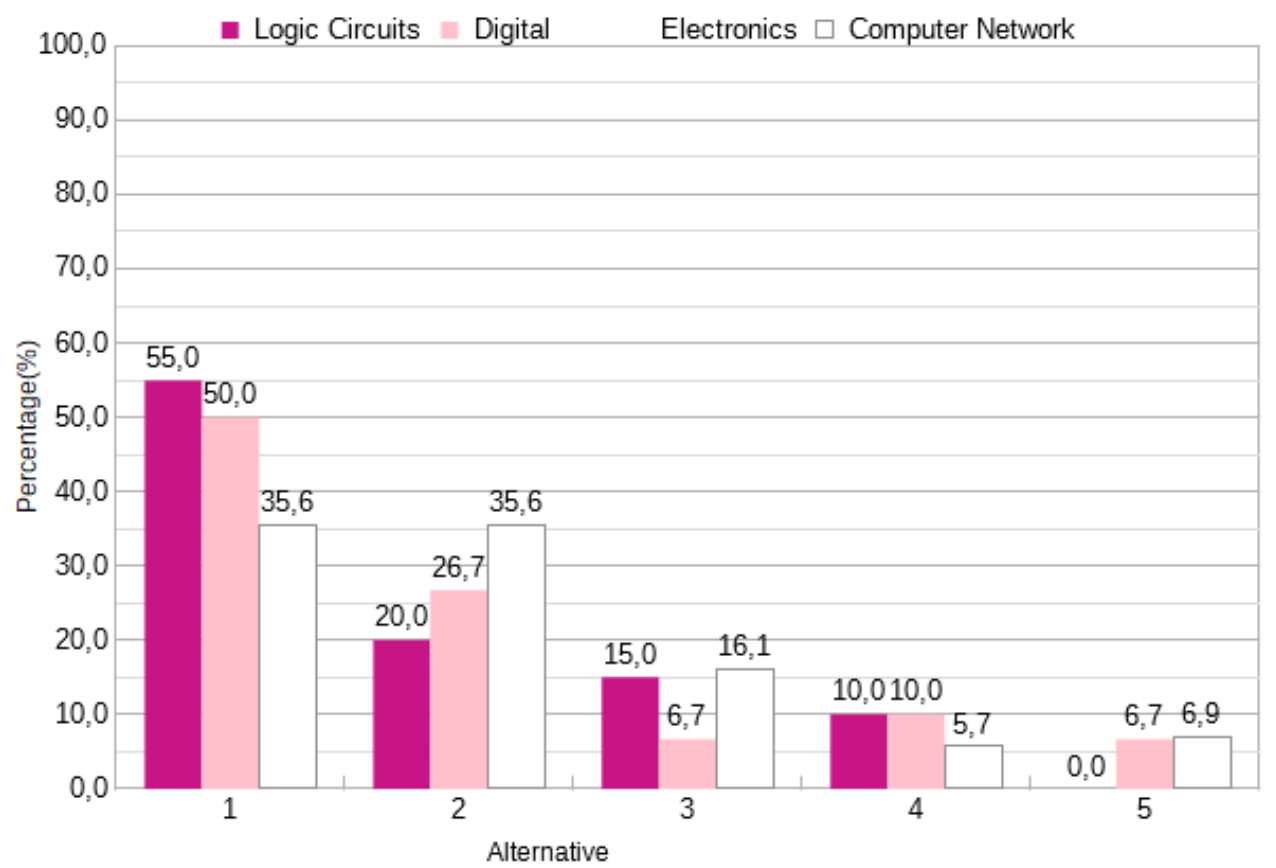

Graphic 11. Affirmative 11 results.

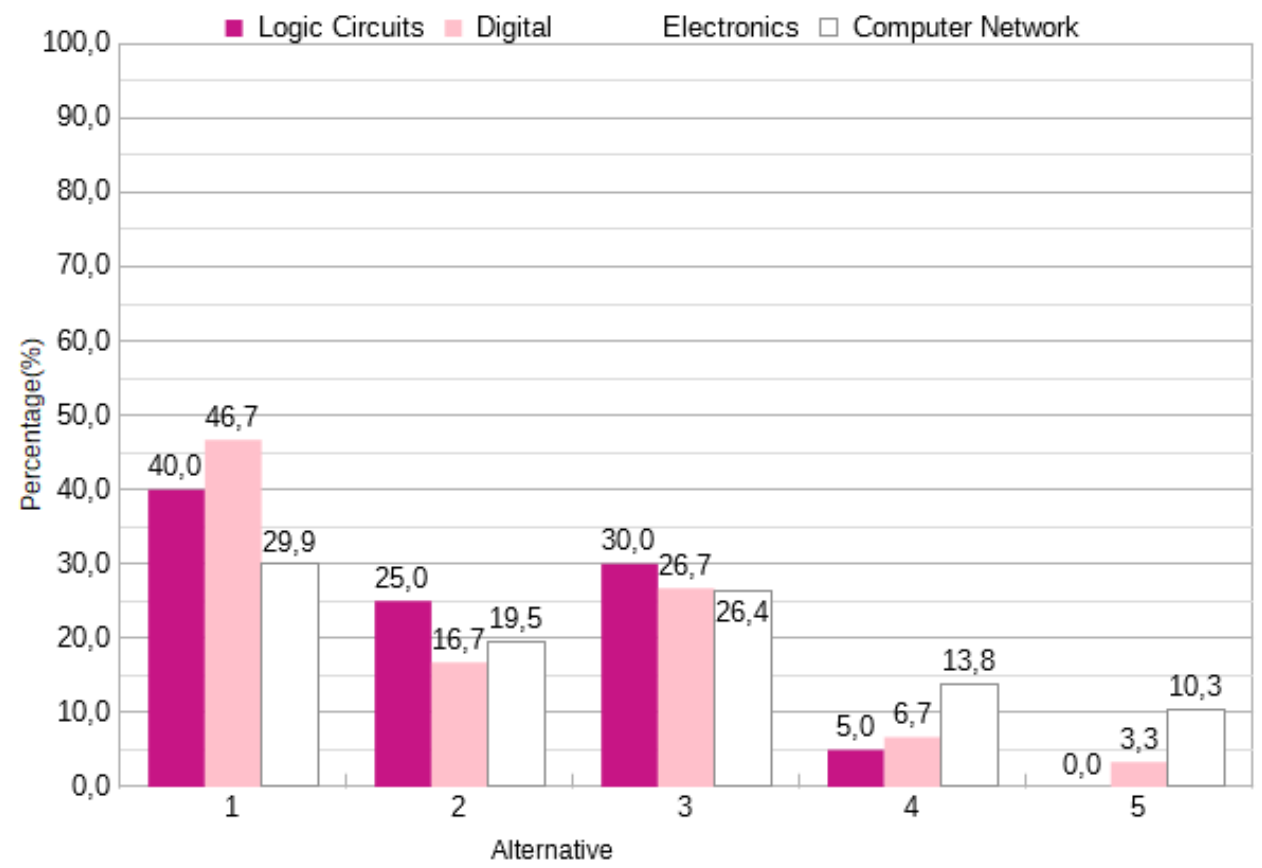

Graphic 12. Affirmative 12 results.

Students were questioned about the main features considered during the choice of the simulator. In this question, they could check different features. Graphic 13 illustrates the 
results on student opinion and preferences. Major cases are clear that student does not consider using paid simulator software and softwares based in free code as Linux. Private preferences are grouped under the "other" option and it is difficult to understand why students can represent multiple interests. For most students, free simulators are the main feature for choosing software. The other features are Windows simulators, graphical interface, online web, available feature and indication. Students widely use the operating system software because of the ease of use. User interfaces facilities allow the student to learn the application faster. In the same cases, simulator indications are considered. Web site pages are easily accessible as the Internet is available.

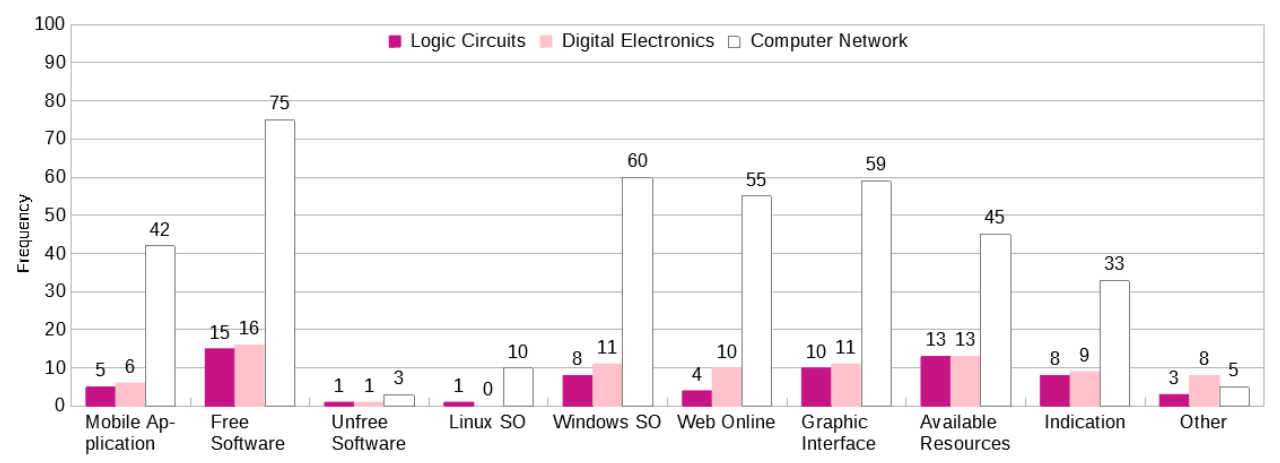

Graphic 13. Simulator choice feature.

The evaluation of students's final results is presented in next graphics. In Graphic 14, students of Logic Circuits showed an improvement of $10.0 \%$ in the percentage of approved by score more than 50 points (between 0 to 100), when started using simulators. In 2013 there is a high percentage approved due to the number of students in the class. In addition, the graphic shows during the simulator applied the average of reproved decreasing over the year. If we consider the averages, it is check: approved $47.9 \%$ and $57.6 \%$, reproved by score $23.0 \%$ and $16.6 \%$, reproved by frequency $24.7 \%$ and $26.5 \%$, give up of discipline $4.4 \%$ and $2.3 \%$, respectively with simulation and not.

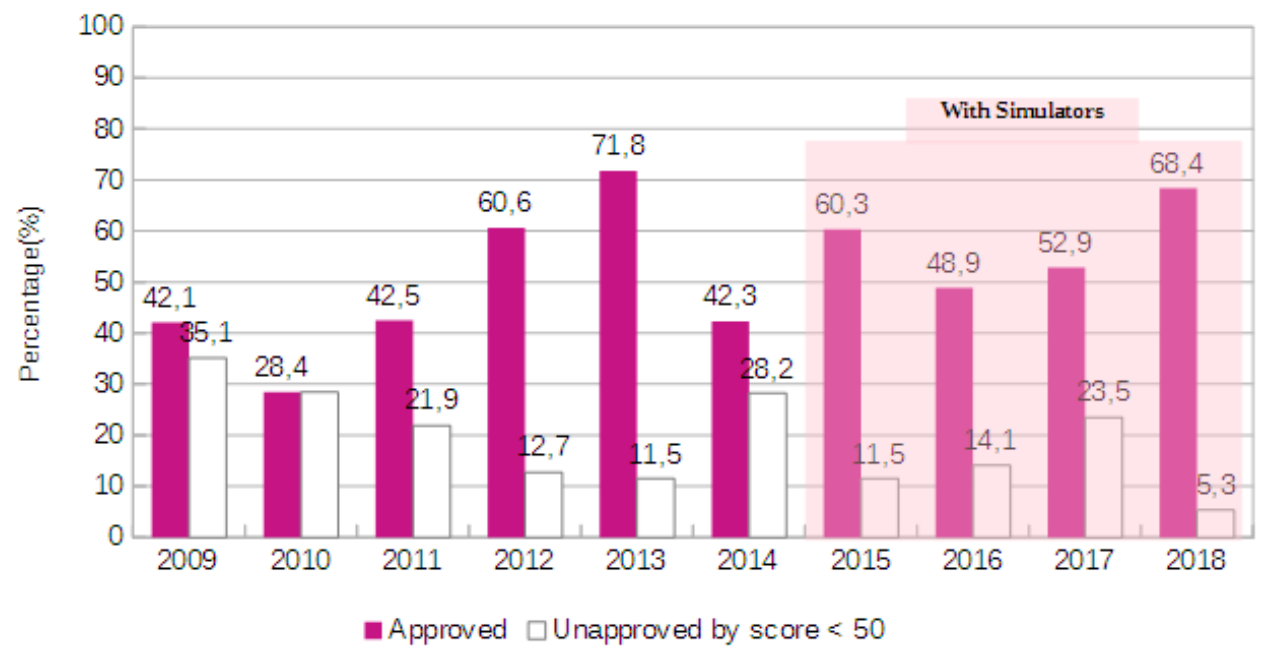

Graphic 14. Final results of Logic Circuits. 
In Graphic 15, the improvement is clear when verified the only class that was used simulators of computer networks. But is necessary to look for a large sample for more years. Over the years, we can show a decrease in the average approved and increasing of average reproved without using the simulators.

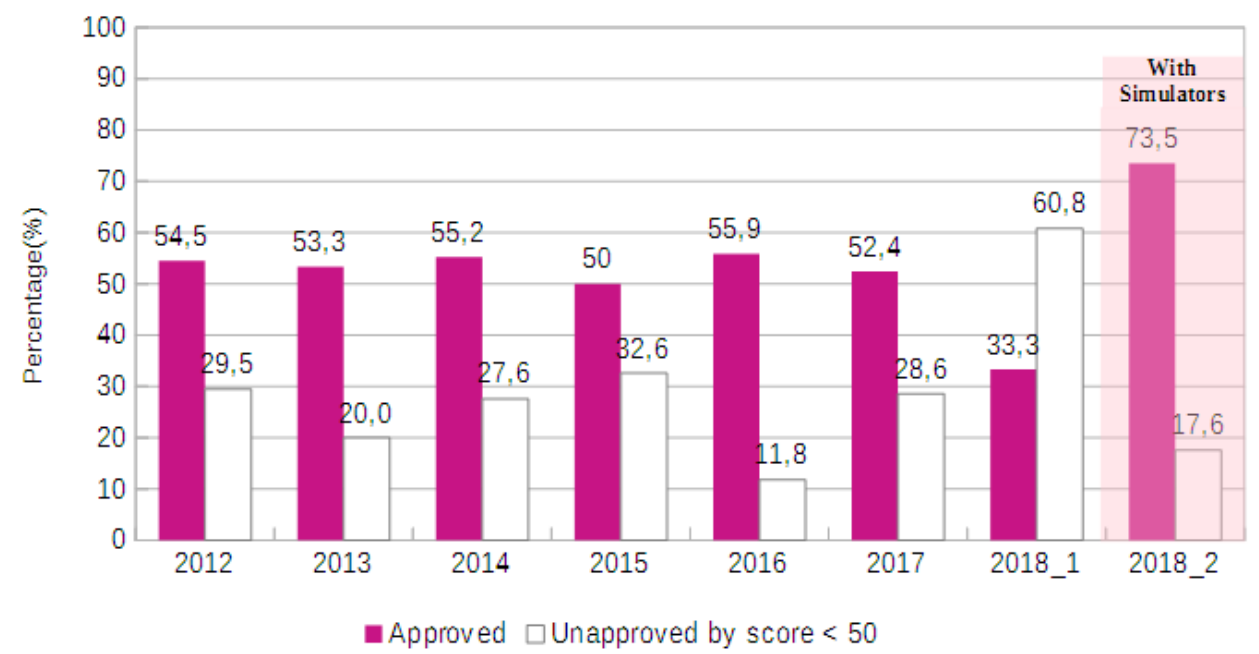

Graphic 15. Final results of Computer Networks.

\section{Conclusions}

Simulator softwares are growing in importance and space during the learning process. In Engineering and Technological courses, learning tools have emerged to improve student recognition. Disciplines such as Electronic and Digital Circuits can be easily added during class to help students understand the basics concepts, establish relationships between theory and practice, solve problems, and improve other skills.

Results show that students positively accept the use of simulator in face-to-face classes in undergraduate and Technological Institutes. Simulators represented an alternative for the understanding process of students and how they can test experiments in a controlled environment before conducting real experiments. For students, simulators are a great alternative, however can not replace real experiments with Electronic components, telecommunications devices and equipment, as well as real conditions.

\section{Reference}

1. GOMES, L. F. EAD no Brasil: Perspectivas e desafios. Avaliação: Revista da Avaliação da Educação Superior, v. 18, n. 1, p. 13-22, 2013. Available in: >http://submission.scielo.br/ index.php/aval/article/view/113548 . Accessed on: 15 aug. 2018.

2. FERREYRA, M. M.; AVITABILE, C.; ÁlvareZ, J. B.; PAZ, F. H.; URZÚA, S. At a crossroads: higher Education in Latin America and the Caribbean. Washington, DC: World Bank Publications, 2017.

3. SILVA, C. A. G.; LIMA, R. U. T.; OlIVEIRA, Z. M. D. S.; PADILHA, A. W.; dos SANTOS, E. L.; SANTOS FILHO, H. T.; PEDROSO, C. M. Análise da Influência da Formação de Ensino Médio no Desempenho Acadêmico de Estudantes de Engenharia. International Journal on Alive 
Engineering Education, v. 3, n. 2, p. 65-78, 2016. Available in: >https://www.revistas.ufg. br/ijaeedu/article/view/44378 . Accessed on: 1 jul. 2018.

4. DILLENBOURG, P.; SCHNEIDER, D.; SYNTETA, P. Virtual learning environments. In: 3rd HELLENIC CONFERENCE INFORMATION AND COMMUNICATION TECHNOLOGIES IN EDUCATION. Kastaniotis Editions, Greece, 2002. p. 3-18. Available in: $<$ https: //telearn.archives-ouvertes.fr/hal-00190701>. Accessed on: 4 jul. 2018.

5. SILVA, C. A. G.; SANTOS, E. L.; PEREIRA, K. L. R.; COELHO, M. M.; PELACINI, D. A. F. Simulation Laboratory for Learning in Electronic Digital Improvements of Learning Electrical Engineering. In: INTERNATIONAL CONFERENCE ON ALIVE ENGINNERING EDUCATION (ICAEEDU). Puerto Iguazú, Misiones, Argentina, 24-29 June 2018.

6. ALONSO, F.; LÓPEZ, G.; MANRIQUE, D.; VIÑES, J. M. An instructional model for webbased e-learning Education with a blended learning process approach. British Journal of educational technology, v. 36, n. 2, p. 217-235, 2005. Available in: $\langle$ https://doi.org/10.1111/j. 1467-8535.2005.00454.x $>$. Accessed on: 4 jul. 2018.

7. PAZOS, J.; AZPIAZU, J., SILVA, A.; RODRÍGUEZ-PATÓN, A. A virtual classroom based on academic memories. Proceedings of Information Society and Education: Monitoring a Revolution, p. 87-92, 2002.

8. FELDER, R. M.; SILVERMAN, L. K. Learning and teaching styles in engineering education. Engineering education, v. 78, n. 7, p. 674-681, 1988. Available in: <http://winbev.pbworks . com/f/LS-1988.pdf $>$. Accessed on: 4 jul. 2018.

9. ARMSTRONG, S. J.;FUKAMI, C. V. The SAGE handbook of management learning, Education and development. Bangalore, India: Sage, 2009.

10. PRINCE, M. J.; FELDER, R. M. Inductive teaching and learning methods: Definitions, comparisons, and research bases. Journal of engineering education, v. 95, n. 2, p. 123-138, 2006. Available in: $\langle$ https://doi.org/10.1002/j.2168-9830.2006.tb00884.x $>$. Accessed on: 30 jun. 2018.

11. SCHMiTT, C. da S.; DOMINGUES, M. J. C. de S. Learning styles: a comparative study. Avaliação: Revista da Avaliação da Educação Superior, v. 21, n. 2, p. 361-386, 2016. Available in: $\langle$ http://dx.doi.org/10.1590/S1414-40772016000200004 >. Accessed on: 10 aug. 2018.

12. FRY, H.; KETTERIDGE, S.; MARSHALL, S. A handbook for teaching and learning in higher education: Enhancing academic practice. New York: Routledge, 2008.

13. SQUIRES, D.; PREECE, J. Predicting quality in educational software. Interacting with computers, v. 11, n. 5, p. 467-483, 1999. Available in: $<$ http://dx.doi.org/10.1016/S0953-5438(98) 00063-0 . Accessed on: 10 aug. 2018.

14. CANT, R. P.; COOPER, S. J. Simulation-based learning in nurse education: systematic review. Journal of advanced nursing, v. 66, n. 1, p. 3-15, 2010. Available in: $<$ https://doi.org/10. 1111/j.1365-2648.2009.05240.x $>$. Accessed on: 10 aug. 2018.

15. REILLY, A.; SPRATT, C. The perceptions of undergraduate student nurses of high-fidelity simulation-based learning: A case report from the University of Tasmania. Nurse Education Today, v. 27, n. 6, p. 542-550, 2007. Available in: <https://doi.org/10.1016/j.nedt.2006. 08.015 . Accessed on: 2 aug. 2018.

16. MCGAGHIE, W. C.; ISSENBERG, S. B.; PETRUSA, E. R.; SCASELE, R. J. Effect of practice on standardised learning outcomes in simulation-based medical education. Medical education, v. 40, n. 8, p. 792-797, 2006. Available in: <https://doi.org/10.1111/j.1365-2929.2006. 02528.x $>$. Accessed on: 9 jul. 2018.

17. BROWN, J. F. Applications of simulation technology in psychiatric mental health nursing education. Journal of Psychiatric and Mental Health Nursing, v. 15, n. 8, p. 638-644, 2008. Available in: $\langle$ https://doi.org/10.1111/j.1365-2850.2008.001281.x $>$. Accessed on: 24 jul. 2018.

18. ARAUJO, R. T. S.; MEDEIROS, F. N. S.; OLIVEIRA, B. F. C.; ARAUJO, N. M. S. Interactive Simulator for Electric Engineering Training. IEEE Latin America Transactions, v. 14, n. 5, p. 2246-2252, 2016. Available in: $<$ https://doi.org/10.1109/TLA.2016.7530420 $>$. Accessed on: 20 jul. 2018 . 
19. WEINGARTNER, E.; VOM LEHN, H.; WEHRLE, K. A performance comparison of recent network simulators. In: IEEE INTERNATIONAL CONFERENCE ON COMMUNICATIONS. IEEE, p. 1-5, Dresden, Germany, 14-18 June 2009. Available in: $<10.1109 /$ ICC. 2009 . 5198657>. Accessed on: 18 jul. 2018.

20. NIKOLIC, B.; RADIVOJEVIC, Z.; DJORDJEVIC, J.; MILUTINOVIC, V. A survey and evaluation of simulators suitable for teaching courses in computer architecture and organization. IEEE Transactions on Education, v. 52, n. 4, p. 449-458, 2009. Available in: <https: //doi.org/10.1109/TE.2008.930097 P. Accessed on: 10 jul. 2018.

21. JANITOR, J.; JAKAB, F.; KNIEWALD, K. Visual learning tools for teaching/learning computer networks: Cisco networking academy and packet tracer. In: SIXTH INTERNATIONAL CONFERENCE ON NETWORKING AND SERVICES. IEEE, p. 351-355, Cancun, Mexico, 713 March, 2010. Available in: $<$ http://doi.ieeecomputersociety.org/10.1109/ICNS.2010. 55 . Accessed on: 11 aug. 2018.

22. BALAMURALITHARA, B.; WOODS, P. C. Virtual laboratories in Engineering education: The simulation lab and remote lab. Computer Applications in Engineering Education, v. 17, $\mathrm{n}$. 1, p. 108-118, 2009. Available in: $\langle$ https://doi.org/10.1002/cae.20186 $>$. Accessed on: 10 jul. 2018.

23. SU, B.; WANG, L. Application of Proteus virtual system modelling (VSM) in teaching of microcontroller. In: INTERNATIONAL CONFERENCE ON E-HEALTH NETWORKING, DIGITAL ECOSYSTEMS AND TECHNOLOGIES (EDT). IEEE, p. 375-378, Shenzhen, China, 17-18 April, 2010. Available in: 〈https://doi.org/10.1109/EDT.2010.5496343 $>$. Accessed on: 11 jul. 2018.

24. TAHEAR, M. T.; KHAN, A. S. Effectiveness of Simulation versus Hands-on Labs: A Case Study for Teaching an Electronics Course. In: ASEE ANNUAL CONFERENCE AND EXPOSITION. Seattle, Washington. 14-17 June, 2015. Available in: https://www.asee.org/ public/conferences/56/papers/13152/download $>$. Accessed on: 11 jul. 2018.

25. MA, J.; NICKERSON, J. V. Hands-on, simulated, and remote laboratories: A comparative literature review. ACM Computing Surveys (CSUR), v. 38, n. 3, p. 7, 2006. Available in: $\langle$ https://doi.org/10.1145/1132960.1132961 $>$. Accessed on: 10 jul. 2018.

26. PLICE, R. K.; REINIG, B. A. Leveraging alumni and business community relations to assess the information systems curriculum. Journal of Education for Business, v. 84, n. 3, p. 142150, 2009. Available in: https://doi.org/10.3200/JOEB.84.3.142-150 $>$. Accessed on: 1 jul. 2018 . 